\title{
Teacher Students' School Memories as a Part of the Development of Their Professional Identity
}

\author{
Virpi Heikkilä \\ Faculty of Education, University of Lapland \\ Lehtikarintie 5-7 a5, 96300 Rovaniemi, Finland \\ Tel: 358-40-740-9847Ｅ-mail: virpi.m.heikkila@gmail.com \\ Satu Uusiautti (Corresponding author) \\ Faculty of Education, University of Lapland \\ (May-Sep) Lepolantie 2, 01830 Lepsämä, Finland \\ (Oct-Apr) 2403 SE 8th Avenue, Cape Coral, 33990, FL, USA \\ Tel: 358-50-355-1280 / 1-239-851-6233Ｅ-mail: satu@uusiautti.fi
}

\begin{abstract}
Kaarina Määttä
Faculty of Education, University of Lapland

P. O. Box 122, 96101 Rovaniemi, Finland
\end{abstract}

Tel: 358-400-696-480Ｅ-mail: Kaarina.Maatta@ulapland.fi

Received: April 2, 2012 Accepted: April 24, 2012 Published: May 1, 2012

doi:10.5296/jse.v2i2.1580 URL: http://dx.doi.org/10.5296/jse.v2i2.1580

\begin{abstract}
Finnish teacher education is highly esteemed since Finnish pupils' success in international PISA comparisons and teacher education is a very popular choice among university applicants. Childhood school experiences are part of the development of a teacher's identity. In this research, the connection between the school memories and the development of teacher students' professional identity is studied in the light of teacher students' memories and narratives. The research was a qualitative research where teacher students were interviewed through theme interview with a narrative approach. The research questions set to this study
\end{abstract}




\section{Macrothink}

were: (1) How are teacher students' school memories connected to the development of professional identity? (2) How are their school memories exploited in teacher education? According to the results, little time is devoted to analyzing teacher students' school memories. Teacher education does not highlight school memories and the significance of teacher students' former teachers and yet, these issues occupy teacher students mind. Teacher education should offer a place where teacher students could reflect their experiences and understand their developing teacher identity.

Keywords: Memories, Professional identity, Teacher education, Class teacher, Teacher student 


\section{Introduction}

Finland is a country that has become famous for its steady success in international Programme for International Student Assessment (PISA) and the university-level Finnish teacher education is considered one of the central factors in explaining success (Kupiainen, Hautamäki, \& Karjalainen, 2009). Success is not, however, self-evident nor is the profession of a classroom teacher the easiest possible-and thousands of Finnish youngsters know that when applying for teacher education. Still, something makes them want to come back to school world and in the classroom although they have almost spent their whole life in there.

Indeed, the teacher has a special significance in a pupil's life during the school years: the teacher is not just someone who guides the pupil toward academic success but the teacher is one of the first authorities outside the pupil's home with whom the pupil learns the basics of interaction (Arikoski, 1999). The time spent at school is never forgotten, and afterwards, people tend to remember the best and the most experiential teaching situations, exceptional circumstances, and personal or peculiar teachers (Määttä \& Uusiautti, 2012). Unpleasant memories, such as public humiliation in front of other people, ridicule, and fear, leave lifelong negative impressions about teachers (Lahelma, 2002; Walls, Sperling, \& Weber, 2001). Alternately, encouraging feedback given by a teacher can even be a significant turning point for the rest of a student's life. Good teachers are aware of the importance of students' emotional health to their academic success (Huebner, Gilman, Reschly, \& Hall, 2009).

The same concerns prospective teachers as well: every teacher student has an idea of a good teacher. The picture is drawn when observing their own teachers' action during their school years. Because of these experience-and regardless of these experiences-teacher students want to become a part of the school world and are willing to raise and teach children.

School experiences are part of the development of a teacher's identity (Vuorikoski, 2003). Those who want to become teachers have gone to school for at least twelve years and observed their teachers. A few years' teacher education cannot just wipe off that image of a teacher and therefore, it is reasonable to ask whether the idea of the teacher's role is imprinted in teacher students' mind already before their education. How much does this idea of a "real" teacher affect the development of teacher students' professional identity and teacherhood?

Reminiscing of one's own school experiences and teachers is important because they have been not only educators and teachers but also adult examples (Törmä, Henrikson, Raehalme, Viskari, \& Vuorikoski, 2004). How well do teacher students realize their own teachers' influence on the development of their own professional identity? According to Vuorikoski (2003), teacher education should include analyzing students' own school memories as an obligatory part of the studies. It would be useful to learn how to reflect and understand the meaning of one's own memories, emotions, and experiences as a part of one's identity and personality. In addition, teacher students should be able to recognize the reasons and motives that got them wanting to become teachers and how their previous experiences and memories will mold them in the teacher's profession (Vuorikoski, 2003). In this research, the connection between the school memories and the development of teacher students' 
professional identity is studied in the light of teacher students' memories and narratives.

\section{Teachers' Professional Identity}

According to Bond (1996), a teacher's professionalism is as difficult to rigorously define as is professionalism in other occupations. Moreover, the foci of the definitions of good teacherhood have changed over the course of time; yet, there has been something permanent in the expectations as well (Darling-Hammond, 2003; Feiman-Nemser, 2003). The teacher's profession has many interpretations: for example, professionalism may refer to quality (Carlgren, 1996), ethicality and moral action (Green et al., 2007), substance knowledge (e.g., Elliott, Isaacs, and Chugani 2010; Jakku-Sihvonen, 2005; Wall \& McAleer, 2000), their personality and individual characteristics have been considered important as well (Hare, 1993; Jennings and Greenberg, 2009). Moreover, professionalism means pedagogical tact, pedagogical eye on various situations and the ability to act as professionally as possible (van Manen, 1991; Määttä \& Uusiautti, 2011a; 2011b; 2012).

The development of teachers' professional identity is also widely studied (Beijaard, Verloop, \& Vermunt, 1999; Woods and Jeffrey, 2002; O’Connor, 2006). Along education and working, the professional identity becomes a part of an individual's identity (Uusiautti \& Määttä, 2011). According to Eteläpelto and Vähäsantanen (2006), a professional identity means a biography-based conception of oneself as a professional actor where work-related values, moral, goals, and beliefs make an important part. A strong professional identity makes one think that he or she possesses the skills required in the occupation, has the ability to be responsible, and knows his or her resources and limits (Laine, 2004). A strong professional identity also consists of constant development and aspiration to strengthen one's talents and identify oneself with the ethics and norms of the occupational field.

The choice of a profession is an important part of the identity development. In addition to financial security, a profession includes a social status and membership in some social community. (Tusin, 1999.) Furthermore, it is worth discussing that teaching is a vocation (Hansen, 1994) or calling, as defined by Duffy and Dik : "calling, defined as an orientation toward a particular life domain, such as work, containing three dimensions: the experience of a transcendent summons originating beyond the self, the pursuit of activity within the work role as a source or extension of an individual's overall sense of purpose and meaningfulness in life, and viewing other-oriented values and goals as primary sources of motivation" (Duffy \& Dik, 2009, p. 35). In teaching profession, vocation covers the following dimensions: (1) a genuine educator's attitude, (2) a positive attitude toward school, (3) respect for the choice of a profession, and (4) profound interest in pupils and their growth (Kari, 1988).

A teacher's professional identity includes an understanding about the meaning of education and rearing and about the beliefs concerning learning. A teacher's professional identity has an influence on how the teacher acts in the classroom and how he or she takes pupils. Through the professional identity, the teacher transmits to pupils the information, skills, and values that he or she finds relevant for teaching and rearing. (Vähäsantanen, 2007.) All in all, a teacher's professional identity develops through dynamic and holistic interaction between its various components and the teacher's past, present, and future are equally important sectors 
of the professional identity (Olsen, 2008; Walkington, 2005).

According to Beijaard, Meijer, and Verloop (2003), a teacher's professional identity (1) is a continuous development process and a life-long learning process, (2) refers to a person within the context, (3) includes sub-identities that consist of relationships and surroundings and may be interconnected and seen as the core of the professional identity, and (4) requires activity of the teacher because the development of a professional identity resembles a constructivist learning process where learning both alone and in cooperation takes place through the learners own activity and action. Likewise, Fullan and Hargreaves (1992) see the contextual nature of the professional development: the basic factors are not only the teacher's goals and personality but also the actual state of the academy and teaching culture.

\section{Method}

\subsection{The Purpose of the Research}

In this research, the purpose was to find out factors that affect the development of teacher students' professional identity. In particular, the emphasis was on their school memories and how teacher students' own childhood teachers' action and work have influenced on the students' developing professional identities.

The research questions set to this study were the following:

(1) How are teacher students' school memories connected to the development of professional identity?

(2) How are their school memories exploited in teacher education?

\subsection{Memories as a Research Target in a Narrative Research}

Memories leave their mark on everyone. These marks turn into narratives that are shared with others and reminisced alone. Then, the narratives become new as the present and the past interweave and the past is remembered in the light of the present moment. Narratives that come up from memories make a significant construction of life experiences. The narrative is an interpretation of life and personal experiences make the general information visible in narratives. (Kutuvina \& Ylitapio-Mäntylä, 2007.) A human being is a creature who interprets his or her world through narratives, understands life events in the form of a narrative, and constructs his or her identity through these narratives (Heikkinen, 2002).

Therefore, memories are information that becomes visible when told and described to someone. Memories and experiences are subjective and therefore different among the research participants. The condition of this kind of research is that the revealed memories are significant and that they reflect the general condition. The courses of action of the society and communities and the contemporary culture come up and live in narratives and memories. (Ylitapio-Mäntylä, 2009). The research participants select what memories they want to share and therefore, their descriptions are interpretations of themselves as kids and school children. The process of reminiscing one's personal life path is already narrative-like (Freeman, 2010). Describing a memory necessitates some kind of a context and the memory itself reveals an 
interactive reality (Becker \& Quasthoff, 2004).

Narrative research can be defined as research that utilizes or analyzes data that is collected via narratives (e.g. biographies) or other such ways (e.g. anthropologists' observational narratives). Thus, a narrative can be either a research object or a means to study a phenomenon (Lieblich, Tuval-Mashiach, \& Zilber, 1998). Narrative research does not focus on objective and generalized facts but on local, personal, and subjective information-this is considered a strength of narrative research because informants' voices of can be heard authentically. Narratives can also be used when analyzing the reasons for actions (see Rubin and Rubin, 1995). In this research, the narrative approach seemed suitable for studying teacher students' school memories and their influence on the development of the teacher students’ professional identity.

At its purest, narrative research can be carried out through a narrative interview where the research participants can freely tell their life story. However, when the purpose is to focus on a certain part of life, it may be appropriate to mold the method to resemble more, for example, a theme interview (Saastamoinen, 1999). Then, the interviewees are not required to produce one long story but short, more carefully select narratives. A theme interview was appropriate because it includes pre-determined themes that were discussed (school memories, special teachers, special events, etc.) but not in a particular order or through strictly defined interview questions (Eskola \& Suoranta, 1998). Although the development of a professional identity is a life-long process, this research was focused on the significance of childhood school memories.

Polkinghorne (1995) distinguishes the analysis of narratives and narrative analysis. The former means categorizing, for example by types, and metaphors. The latter refers to the composition of a new narrative based on various original narratives. The first analysis method was used in this research: the participants' narratives were categorized by predetermined categories. The analysis was made using narrative structuring that tries to put together a cohesive narrative of experiences and events during interviews (Kvale, 1997). Furthermore, the analysis typified a category-content-focused approach, with parts of narratives being placed in different categories (Lieblich, Tuval-Mashiac, \& Zilber, 1998).

Six teacher students from the Faculty of Education, University of Lapland, were interviewed. Three of them were women and three were men, aged between 22-27 years and at the time of data collection, they had studied already 2.5 years. When it comes to their childhood elementary schools, four of them had gone to a 20-200 pupils' village school and two in a bigger 350-400 pupils' school in a city. They had had between ten and 35 pupils in their class. Two interviewees had studied in a multigrade class.

Before the actual interview, the interviewees could familiarize themselves with the interview questions and think about their memories beforehand. The longest interview took one hour and 28 minutes and the shortest was 38 minutes. After writing the transcript, the interview data was categorized according to the themes the research interview had covered. The analysis of narratives was thus implemented through gathering common elements and categories from the data. These categories functioned as the basis for the interpretation. 


\section{Results}

\subsection{Memories of Childhood Schools and Teachers}

The interviewees' memories of school were mostly positive. Going to school had been nice and fun. Being able to meet friends, finding learning fun and easy, and some specific, likable teachers were reasons that the teacher students used when explaining their school satisfaction. Time spent at the elementary school did however include worse memories, too, as three of the interviewees reported being bullied at school. Nevertheless, bullying was not the topmost memory. In general, the interviewees described their own class as a pleasant and stable community with a good atmosphere. The memories were described for example like this:

"Well, I liked school very much. I can't remember if there was anything that had made me not wanting to go to school in the morning. So, our school was a real nice and safe place...”

"Well, it was completely nice time... and I have very warm memories of teachers and the atmosphere as well."

Some school subjects were perceived more likable than others and when discussed more profoundly, several reasons were found. In addition to their own talents, the content of lessons, teachers' various teaching methods, and the teacher students' own interest came up as the most significant reasons:

"Perhaps my own interest in it was a bigger factor combined to the teacher's own enthusiasm about the subject, so that made me like some subjects."

"Well, the teacher certainly has had a huge role in all these things that why it is PE; a sort of relaxed atmosphere and doing things in a good spirit."

The features of teacher students' childhood teachers were discussed widely. The interviews were asked to describe their former teachers with a few words. It became evident that each of the interviewees had a few teachers who they remembered the best. The most unforgettable features were the teachers' personality and behavior. The way the participants described teachers was focused on drawing a picture of an adult with all his or her characteristics and habits but some externals were mentioned too. Features, such as charisma, personality, and style of speaking were mentioned more often than routine things from the lessons. Teachers' ways of action, their teaching methods, and classroom management were discussed.

Three types of teachers could be found in the interviewees' narratives: (1) a kind and motherly (usually female) teacher who could manage the classroom, (2) a relaxed and convivial (male in all narratives) teacher with whom pupils had projects and other activities, and (3) a strict and serious teacher who did not leave any positive memories. The teachers were described for example in the following manner:

"Anne, who was my first teacher, has naturally stuck in my mind. She was a really sweet woman and sometimes we would visit her on Fridays to make pan cakes. She was a nice old lady...”

“He was sort of, I don’t know if you can call him convivial, but a younger man, about thirty 
years old... We had a safe atmosphere and fair, it felt fair and just, but he could also use humor and staff”

"She was a bit, you know, strict partly, so she didn't accept disturbance and sometimes she was a bit too strict. I think sometimes we didn't necessarily disturb when we talked about for instance school work with some other pupil and she would remark on that. She was a young teacher.”

Although teachers of the above-mentioned types were the most evident in the interviewees' stories, some neutral, "kind of nice" teachers were also mentioned but usually, the interviewees did not have anything else to tell about them.

\subsection{School Memories and the Development of a Teacher Identity}

Almost all interviewees told that they contemplate their school time every now and then. School memories were strongly connected with the understanding about what is here and now. Two of the interviewees reported that they sometimes think about how their own teachers had acted and either wanted to take their cue from them or act in a totally different manner. School memories had left them a general picture of elementary school. They could remember teachers, classmates, and significant events well while the contents of lessons were forgotten in the course of life.

After school memories, the interviewees were asked to think about themselves in situations they had described. When discussing positive memories, the teacher's action was perceived so professional that the interviewees wanted to act in a somewhat similar manner. Naturally, when it came to negative memories, they would not follow their former teacher's example. Therefore, the experienced joy or injustice had influenced on their idea of how they would act as teachers. However, none of the interviewees had perceived that they actually would have acted, talked, or behaved in a similar manner than their teachers. Yet, two of the male students told that they had adopted certain ways of action, gestures, or basic composition from their own male teachers.

The teacher students were also able to name several means of classroom management or teaching methods that they wanted adopt from their former teachers. Mostly, they would, however, highlight the features of their teachers' being or behavior:

“...on Fridays, we had that singing; so some sort of common moment, it doesn't have to be singing necessarily... but a sort of ending to the week.”

“...you know, natural sciences, and physics and chemistry... sort of elucidation of thins when he taught us and it seemed really nice; so the way you can handle those things...”

“...if we had bullying, they would intervene immediately and took the pupils and discuss with the bully and the bullied and things like that which are really good methods in my opinion and work well... you can say that they are totally the offering of the elementary school...”

The teacher students wanted to adopt from their teachers, for example, the routines of starting 
or ending a lesson, common excursions, projects and group works, and a sort of "touch" with teaching and pupils. Putting someone on the corner, yelling in the classroom, and intimidating were methods that they did not want to copy from their teachers. The general perception was that methods and habits were mostly provided in education and teaching practicums and manners adopted from their former teachers are not the topmost things in mind when planning their teaching. However, they seemed to be aware of the possible influence.

\subsection{School Memories and Teacher Education}

According to the interviews, teacher education had provided the teacher students with merely theoretical and substance knowledge while teacherhood and the teacher's professional identity were less discussed. All teacher students did however mention that they think about themselves as prospective teachers quite often. Five of the students thought that their school memories had an important role and were useful when considered from the point of view of their professional development. Here are two examples how this was revealed in the interviews:

"Well, I think they are quite important because the time spent at school is such a big part of your life and especially you childhood, and a lot of those experiences of development have happened then... I have recalled really much of those school memories and it's a good thing, good and bad memories, and when you're older you can process them more and contemplate the reasons and you don't see everything so black-and-white...”

"I think they [school memories] are really important and surely I have gotten plenty of new ideas and others things and ways of thinking and how to teach and such from here too but I believe that your life history is the foundation of all and you transmit your good experiences in your teaching. And then those bad experiences that you've had and that are really bad, I have been thinking that I won't teach like that at all. So, your own experiences have a great emphasis."

The interviewees mentioned the connection between their experiences and their personality and teacher identity in many contexts. Although school memories were regarded as significant, some of the teacher students told how difficult it is to distinguish how certain school memories have influenced on their teacherhood. School, hobbies, and home have all formed their life and subconsciously affect what one is today (see also Kivel, 1998).

The teacher students were asked to describe what kind of teachers they wanted to be. Seven features or types occurred: (1) inspiring and active, (2) a good role model and example, (3) safe, present, and trustworthy, (4) an authority who is able to set limits, (5) capable of teaching manners and other life skills, (6) equitable and fair-minded, and (7) fair and relaxed. Five of the teacher students explained that they had picked these features from their former teachers and created a model of a good teacher that they wanted to follow in their own work:

"I think that those teachers who I've had and liked a lot have had these features and I have found them important...” 
Three of the teacher students mentioned that teacher education and teaching practicums had provided them with advice and instructions on how to act in teaching and rearing situations. However, they thought that the most advice had come from their own personality and life experience. The development of the professional identity is based on the teacher students' values and rearing, life experiences, personality, and others' behaviors that they have perceived moral in their childhood and adolescence. However, teacherhood and the development of professional identity are not profoundly analyzed in teacher education but left to students themselves. Although the students' idea of themselves as teachers had crystallized and specified, the idea had not changed much during teacher education. According to the interviewees' narratives, education had given the understanding about the multidimensional nature of the teacher's profession, various pedagogical and didactic methods, and the meaning of cooperation.

\section{Discussion}

According to the results, little time is devoted to analyzing teacher students' school memories. Teacher education does not highlight school memories and the significance of teacher students' former teachers and yet, these issues occupy teacher students mind. The development of the students' professional identity is mainly their own responsibility as teacher education is mostly focused on substance matter and theoretical perspectives of teaching and learning.

At the beginning of teacher education, a teacher student sets goals that support his or her professional development. However, based on the results, the need for making the students' preconception of the teacher's profession explicit was evident. The task of teacher education is to produce as realistic image of the profession as possible that would function as the foundation of the development of teacher students' professional identity.

As the teacher's professional identity is constructed on students' previous experiences, many of them from their elementary schools, the teacher students' history and developing teacher identity should confront already during teacher education (Zehm, 1999). The professional identity will not be strong and well-developed until the teacher discovers the definition of a teacher's work through his or her personal experiences (Perttula, 1999). Furthermore, the teacher's personality is a tool along with teacher's manuals and text books, and therefore, the definition of teacherhood wells from inside, from the teacher's personality. The teacher's personal life, experiences, and school memories cannot be regarded as a separate part of the teacher's professional identity: everything that the teacher brings in the classroom is part of the teacher's institutional biography. (Salo, 2005.)

\section{Conclusion}

Today's research on professional identities emphasizes the complex and ever-changing nature of the balance between one's social and personal identity (Eteläpelto \& Vähäsantanen, 2006). Continuously changing school world and its new demands also challenge teachers' professional identities and lay stress on constant reflection and development. Indeed, it has been argued that professional development emphasizes the importance of changing its form 
(e.g. Birman et al., 2000). Today, the ability to consciously control one's behavior is important in every occupation, including teaching: people of this kind are persistent, flexible, and apter to have positive emotions than negative ones and to handle the stressful situations in life efficiently (Baltes \& Freund, 2006). This is important when considering the example that today's teacher set: they are the ones who act in memories of the future teachers.

Based on the results, teacher students' school memories seemed to have an important role in the development of their professional identity but in order to understand this significance and to make use of them, personal contemplation is required. The role of quality supervision for the professional development must be recognized (see also Stoltenberg, 2005). Understanding one's own history, life path, is important also to the overall development of one's identity. Teacher education should offer a place where teacher students could reflect their experiences and understand their developing teacher identity.

During teacher education, teacher students are supposed to find those characteristics that are the most important to their own teacherhood-but the identity will still be shaped work years. Laursen (1996) points out that the development of a teacher's professional identity has to be built on the idea of a good teacher. That is a respectable goal. Yet, the idea of good teacherhood is not any new invention but might be more topical than ever within the turmoil of changing societies. For example, Uno Cygnaeus (1910) sublimely described good teacherhood in Finland by noting:

Knowledge cannot alone be ennobling. Knowledge has to be molded into living conviction that would lead into inner noble-mindedness. Teaching must be educative and marked by the spirit of diligence, not mugging up whatsoever but merely action that develops harmoniously soul and body. Every teacher has to blaze with the spirit of sacred love. Sacred love that does not seek its own, that does not look at the present but the future; love that can even punish when considered necessary. That kind of love towards pupils has to smolder in a teacher's heart. That kind of teacher's love affects the whole school in a protecting way. (Cygnaeus, 1910, p. 197)

Teachers are the ones who can offer these positive experiences to pupils. Indeed, teachers, if anyone, know that emotion-based attachments are bridges between people. Everyone should be able to have experiences of love, caring, and attachment during their whole life (Fromm, 1956), including school time. Therefore in addition to theoretical, practical, and substance knowledge, teacherhood must be based on a profound understanding about the influence of childhood events on teacher students' present identity - and on their future identity as teachers as well.

\section{References}

Arikoski, J. (1999). Vuorovaikutus opetustyössä [Interaction in teaching]. In P. Räsänen, J. Arikoski, P. Mäntynen, \& J. Perttula (Eds.), Opettajuuden psykologia [The psychology of teacherhood]. Jyväskylä: University of Jyväskylä.

Baltes, P. B., \& Freund, A. M. (2006). Ihmisen vahvuudet ja viisaus [The human strengths and wisdom]. In L. G. Aspinwall \& U. M. Staudinger (Eds.), Ihmisen vahvuuksien psykologia 
[A psychology of human strengths] (pp. 34-46). Helsinki: Edita.

Becker, T., \& Quasthoff, U. M. (2004). Different dimensions in the field of narrative interaction. In T. Becker \& U. M. Quasrhoff (Eds.), Narrative interaction (pp. 1-12). Amsterdam: John Benjamins.

Beijaard, D., Meijer, P. C., \& Verloop, N. (2003). Reconsidering research on teacher's professional identity. Teaching and Teacher Education, 20, 107-128.

Beijaard, D., Verloop, N., \& Vermunt, J. D. (1999). Teachers' perceptions of professional identity: an exploratory study from a personal knowledge perspective. Teaching and Teacher Education, 16, 749-764.

Birman, B. F., Desimone, L., Porter, A. C., \& Garet, M. S. (2000). Designing professional development that works. Educational Leadership, 57(8), 28-33.

Bond, W. R. (1996). Teachers’ professionalism: overview. In M. Kompf, W. R. Bond, D. Dworet, \& R. T. Boak (Eds.), Changing research and practise: teacher's professionalism, identities and knowledge (pp. 5-8). London: Falmer Press.

Carlgren, I. (1996). Professionalism and teachers as designers. In M. Kompf, W. R. Bond, D. Dworet, \& R. T. Boak (Eds.), Changing research and practise: teacher's professionalism, identities and knowledge (pp. 20-32). London: Falmer Press.

Darling-Hammond, L. (2003). Keeping good teachers: Why it matters, what leaders can do. Educational Leadership, 60(8), 6-13.

Duffy, R. D., \& Dik, B. J. (2009). Beyond the self: external influences in the career development process. The Career Development Quarterly, 58, 29-44.

Elliott, E. M, Isaacs, M. L., \& Chugani, C. D. (2010). Promoting self-efficacy in early career teachers: A principal's guide for differentiated mentoring and supervision. Florida Journal of Educational Administration and Policy, 4(1), 131-146.

Eskola, J., \& Suoranta, J. (1998). Johdatus laadulliseen tutkimukseen [Introduction to qualitative research]. Tampere: Vastapaino.

Eteläpelto, A., \& Vähäsantanen, K. (2006). Ammatillinen identiteetti persoonallisena ja sosiaalisena konstruktiona [Professional identity as a personal and social construction]. In A. Eteläpelto \& J. Onnismaa (Eds.), Ammatillisuus ja ammatillinen kasvu [Professionalism and professional growth] (pp. 26-49). Helsinki: Kansanvalistusseura.

Feiman-Nemser, S. (2003). What new teachers need to learn. Educational Leadership, 60(8), 25-29.

Freeman, M. (2010). Telling stories: memory and narrative. In S. Radstone \& B. Schwarz (Eds.), Memory: histories, theories, debates (pp. 263-277). New York, NY: Fordham University Press.

Fullan, M., \& Hargreaves, A. (1992). Teacher development and educational change. London: 
Falmer Press.

Gardner, H., Csikszentmihalyi, M., \& Damon, W. (2001). Good work. When excellence and ethics meet. New York, NY: Basic Books.

Green, S. K., Johnson, R. L., Kim, D.-H., \& Pope, N. S. (2007). Ethics in classroom assessment practices: Issues and attitudes. Teaching and Teacher Education, 23(7), 999-1011.

Hansen, D. T. (1994). Teaching and the sense of vocation. Educational Theory, 44(3), 259-275.

Hare, W. (1993). What makes a good teacher: Reflections on some characteristics central to the educational enterprise. London and Ontario: The Althouse Press.

Heikkinen, H. (2002). Tarinat opettajankoulutuksen välineenä [Narratives as a means of teacher education]. In H. Heikkinen \& L. Syrjälä (Eds.), Minussa elää monta tarinaa, kirjoituksia opettajuudesta [Many narratives live inside me, writings about teacerhood] (pp. 100-105). Helsinki: Kansanvalitusseura.

Huebner, E. S., Gilman, R., Reschly, A. L., \& Hall, R. (2009). Positive schools. In S. J. Lopez \& C. R. Snyder (Eds.), Oxford handbook of positive psychology (pp. 561-568). Oxford: Oxford University Press.

Jakku-Sihvonen, R. (2005). Kasvatustieteiden opetus ja asiantuntijan arkipätevyys [Education of the educational sciences and expert's everyday competence]. In R. Jakku-Sihvonen (Ed.), Uudenlaisia maistereita. Kasvatusalan koulutuksen kehittämislinjoja [New kinds of masters: developmental guidelines of education of the educational sciences] (pp. 125-150). Jyväskylä: PS-kustannus.

Jennings, P. A., \& Greenberg, M. T. (2009). The prosocial classroom: teacher social and emotional competence in relation to student and classroom outcomes. Review of Educational Research, 79(1), 491-525. http://dx.doi.org/10.3102/0034654308325693

Kari, J. (1988). Opetus- ja kasvatustyö ammattina [Teaching and rearing as a profession]. Helsinki: Otava.

Kivel, B. D. (1998). Adolescent identity formation and leisure contexts: a selective review of literature. The Journal of Physical Education, Recreation and Dance, 69, 36-43.

Kupiainen, S., Hautamäki, J., \& Karjalainen, T. (2009). The Finnish education system and PISA. Finland: Ministry of Education. Retrieved from: http://www.pisa2006.helsinki.fi/files/The_Finnish_education_system_and_PISA.pdf (March 30, 2012).

Kvale, S. (1997). Den kvalitativa forskningsintervjun [The qualitative interview]. Lund: Studentlitteratur.

Laine, T. (2004). Huomisen opettajat [Tomorrow's teachers]. Tampere: Tampere University Press. 
Laursen, P. (1996). Professionalism and the reflective approach to teaching. In M. Kompf, W. R. Bond, D. Dworet, \& R. T. Boak (Eds.), Changing research and practise: teacher's professionalism, identities and knowledge (pp. 48-55). London: Falmer Press.

Lahelma, E. (2002). School is for meeting friends: secondary school as lived and remembered. British Journal of Sociology of Education, 23(39), 367-381.

Lieblich, A., Tuval-Machiach, R., \& Zilber, T. (1998). Narrative research: Reading, analysis and interpretation. Thousand Oaks, CA: Sage.

Määttä, K., \& Uusiautti, S. (2011a). How to enhance the smoothness of university students' study paths? International Journal of Research Studies in Education, 1(1), 47-60. http://dx.doi.org/10.5861/ijrse.2012.v1i1.16

Määttä, K., \& Uusiautti, S. (2011b). Pedagogical love and good teacherhood [online]. in education, 17(2). Retrieved from: http://ineducation.ca/article/pedagogical-love-and-good-teacherhood

Määttä, K., \& Uusiautti, S. (2012). Pedagogical authority and pedagogical love - connected or incompatible? International Journal of Whole Schooling, 8(1), 21-39.

O’Connor, K. (2006). "You choose to care”: Teachers, emotions and professional identity. Teaching and Teacher Education, 24, 117-126.

Olsen, B. (2008). How reasons for entry into the profession illuminate teacher identity development. $\quad$ Retrieved from: http://www.teqjournal.org/TEQ\%20Website/Back\%20Issues/Volume\%2035/VOL35\%20PDF S/35_3/07olsen-35_3.pdf (March 13, 2012).

Perttula, J. (1999). Mitä opettajuus on? Ydinkysymyksiä ja vastausten alkuja [What is teacherhood? Core questions and beginning answers]. In P. Räsänen, J. Arikoski, P. Mäntynen \& J. Perttula (Eds.), Opettajuuden psykologia [The psychology of teacherhood] (pp. 12-61). Jyväskylä: Yliopistopaino.

Rubin, H. J., \& Rubin, I. S. (1995). Qualitative interviewing. The art of hearing data. Thousand Oaks, CA: Sage.

Saastamoinen, M. (1999). Narratiivinen sosiaalipsykologia - teoriaa ja menetelmiä [Narrative social psychology - theory and methods]. In J. Eskola (Ed.), Hegelistä Harréen narratiivista nudistiin [From Hegel to Harré, from narrative to Nudist] (pp. 165-192). Kuopio: University of Kuopio.

Salo, U. (2005). Ankarat silkkaa hyvyyttään. Suomalainen opettajuus [Strict just because of their goodness. The Finnish teacherhood]. Helsinki: WSOY.

Stoltenberg, C. D. (2005). Enhancing professional competence through developmental approaches to supervision. American Psychologist, 6, 857-864.

Tusin, L. (1999). Deciding to teach. In R. P Lipka \& T. M. Brinthaupt (Eds.), The role of self in teacher development (pp. 11-35). Albany, NY: State University of New York. 


\section{Macrothink}

Journal of Studies in Education

ISSN 2162-6952

2012, Vol. 2, No. 2

Törmä, T., Henrikson, L., Raehalme, O., Viskari, S., \& Vuorikoski, M. (2004).Yhteinen matka ja tuliaiset [Common journey and gifts]. In M. Vuorikoski \& T. Törmä (Eds.), Opettaja peilissä, katse ammatilliseen kasvuun [The teacher in the mirror, a look at the professional growth] (pp. 177-188). Vantaa: Dark Oy.

Uusiautti, S., \& Määttä, K. (2011). The process of becoming a top worker. International Education Studies, 4(4), 69-79. http://dx.doi.org/10.5539/ies.v4n4p69

van Manen, M. (1991). The tact of teaching: The meaning of pedagogical thoughtfulness. London: Althouse Press.

Vuorikoski, M. (2003). Valta ja sukupuoli opettajaksi opiskelevien koulumuistoissa [Power and gender in the teacher students' school memories]. In M. Vuorikoski, S. Törmä, \& S. Viskari (Eds.), Opettajan vaiettu valta [The teacher's unspoken power] (pp. 131-154). Tampere: Vastapaino.

Vähäsantanen, K. (2007). Ammatillisen opettajan ammatti-identiteetti muutoksessa [The occupational teacher's professional identity in change]. In A. Eteläpelto, K. Collin, \& J. Saarinen (Eds.), Työ, identiteetti ja oppiminen [Work, identity, and learning] (pp. 156-176). Helsinki: WSOY.

Walkington, J. (2005). Becoming a teacher: encouraging development of teacher identity through reflective practice. Asia-Pacific Journal of Teacher Education , 33(1), 53-64.

Wall, D., \& McAleer, S. (2000). Teaching the consult teachers: Identifying the core content. Medical Education, 34(2), 131-138.

Walls, R. T., Sperling, R. A., \& Weber, K. D. (2001). Autobiographical memory of school. The Journal of Educational Research, 95(23), 116-127.

Woods, P., \& Jeffrey, R. (2002). The reconstuction of primary teacher's identities. British Journal of Sociology of Education, 23(1), 89-106.

Ylitapio-Mäntylä, O. (2009). Lastentarhanopettajien jaettuja muisteluja sukupuolesta ja vallasta arjen käytännöissä [Early chilhood educators' shared memories of gender and power in everyday practices] (Doctoral dissertation). Rovaniemi: University of Lapland.

Zehm, S. J. (1999). Deciding to teach: Implications of a self-development perspective. In R. P. Lipka, \& T. M. Brinthaupt (Eds.), The role of self in teacher development (pp. 36-54). Albany, NY: State University of New York.

\section{Copyright Disclaimer}

Copyright reserved by the author(s).

This article is an open-access article distributed under the terms and conditions of the Creative Commons Attribution license (http://creativecommons.org/licenses/by/3.0/). 